\title{
Methodology for the biofunctional assessment of honey (Review)
}

\author{
IOANNIS D. KYRIAZIS, ZOI SKAPERDA, FOTIOS TEKOS, SOTIRIA MAKRI, \\ PERIKLIS VARDAKAS, ELENI VASSI, ANASTASIA PATOUNA, KALLIRROI TERIZI, \\ CHRISTOS ANGELAKIS and DEMETRIOS KOURETAS
}

Department of Biochemistry and Biotechnology, University of Thessaly, 41500 Larissa, Greece

Received February 4, 2021; Accepted March 24, 2021

DOI: $10.3892 /$ ijfn.2021.15

\begin{abstract}
Current concerns over the modern health status have been transpired due to the desire of consumers to gain the benefits of quality biofunctional foods, and the will of producers to improve the scalability of their products. The constant flow of scientific knowledge and technology manifests the progressive exploitation of the biological capacity of foods to produce an economic output. Therefore, the assessment of specific properties that agricultural products contain, is a prerequisite prior to their entering the market. In the present review article, a wide array of methodologies is proposed which may be used to evaluate the antioxidant, reductive and DNA protective capacity of honey at cell-free, cell-based in vitro and in vivo experimental levels. This proposed array is compiled by non-laborious techniques that do not demand sophisticated and expensive equipment. Moreover, they can be followed by scientists to screen different honey batches and other agricultural goods that will allow enhanced repeatability and comparability among studies.
\end{abstract}

\section{Contents}

1. Introduction

2. Oxidative stress and counteractive mechanisms

3. In vitro cell-free system measurements

4. In vitro measurements in cell cultures

5. In vivo measurements

6. Conclusion and future perspectives

\section{Introduction}

It is widely accepted that nutrition constitutes the main pillar which ensures a better quality of life and assists in the prevention of pathophysiological conditions. In recent

Correspondence to: Professor Demetrios Kouretas, Department of Biochemistry and Biotechnology, University of Thessaly, Viopolis, Mezourlo, 41500 Larissa, Greece

E-mail: dkouret@uth.gr

Key words: oxidative stress, honey, functional foods, methods, antioxidant years, the scientific community has aimed to shed light onto the discovery of natural products that contribute towards a healthier and more balanced diet. Agricultural products constitute the major source of interest of scientists, who aim to elucidate the specific biological properties that will have a beneficial overall effect on nutrition and well-being.

Even though the Mediterranean Basin covers only $1.6 \%$ of the global land surface, it constitutes one of the world's richest sources of flora and fauna diversity. More specifically, the Mediterranean Basin comprises of 25,000 flowering plants, with almost half of these being endemic, representing $10 \%$ of all known plants worldwide $(1,2)$. This has led to the Mediterranean Basin being recognized as one of the top 25 global biodiversity hotspots (3). Greece represents one of the most rich-in-flora territories of the Mediterranean Basin, since almost 6,000 species have been reported (4). The pharmacological or nutritional use of regional flora has been extensively reported even in ancient years, where the empirical administration of botanies was used for healing or deterrent purposes. In recent years, despite the criticism concerning the French paradox $(5,6)$, interest has arisen around nutrition, emphasizing the crucial effects of a healthy diet on lifestyle (7). It was epidemiologically observed that the French initially, and later the Mediterranean population, exhibited a relatively low incidence of coronary heart disease (CHD) that may be attributed to antioxidant-rich foods consumed and their cumulative effects $(8,9)$, despite the consumption of a high fat diet (10).

To a certain extent, honey is considered one of the cornerstones of the Mediterranean diet and is produced from the insect Apis mellifera. Greek honey is a natural food product, which in addition to its nutritional importance, possesses valuable chemopreventive properties due to the presence of bioactive ingredients, mainly divided into its antibacterial and antioxidant capacity (11). These two pillars affect each other, and their combination engenders the high health-promoting properties of honey (12-17). Honey is characterized by its content variability since it is produced through water evaporation and the regurgitation of different plant nectars (18). Thereafter, different Apis mellifera habitats result in different honey compositions, since the flora species from which honeybees collect their nectar are dissimilar. Even though beekeepers acknowledge the habitat and the flowering plants it comprises, the composition and unique properties of honey remain elusive and can be only attributed to empirical and theoretical bases. Additionally, multicomponent analysis of honey batches will 
allow the discrimination of natural and adulterated honey (19), reinforcing commercial value and consumers trust over honey quality.

To this end, it is of paramount importance to use scientific tools that will determine the beneficial properties of diverse agricultural products and more specifically, honey. The proposed methodology that is presented in the present review article determines the polyphenol content of honey gels with or without pollen and how this affects their antioxidant capacity (Fig. 1). This readout spectrum that includes biochemical and molecular parameters (Fig. 2), allows for the creation of a tag that describes the antioxidant potential that can improve the human body redox status through its ability to scavenge produced free radicals. Antioxidant capacity determination will allow scientists, producers and consumers to discern the quality of its produced batch that is able to certify health benefits and add product value. This effort to use easy-to-obtain readouts with well-established techniques will ensure scientific integrity, comparability and repeatability. The aforementioned may also promote interest in the Mediterranean diet that has been undoubtedly shown to be associated with longevity and an improved quality of life (20).

\section{Oxidative stress and counteractive mechanisms}

A free radical is defined as a highly reactive and short-lived atom or molecule that possesses an unpaired valence electron. Its properties allow a reaction with adjacent molecules through reduction-oxidation chemical reaction (redox). This process does not only heavily affect nearby molecules, but also allows unpaired electrons to be transferred from a target to a secondary target, creating a biochemical cascade and network of pro-oxidant molecules (20). The most important free radicals are molecules in which their chemical core is occupied by oxygen, nitrogen or occasionally carbon.

Free radicals are produced at cellular levels physiologically and are signaling molecules that contribute to different fundamental cellular (cell cycle, cell growth, cell adhesion, programmed cell death and chemotaxis) and molecular (gene expression, protein functions, protein-protein interactions, $\mathrm{Ca}^{2+}$ buffering and redox homeostasis) programs (21). They are mainly produced in the mitochondrial electron transport chain, NADPH oxidases, xanthine oxidases and nitric oxidases. Internally they can be further produced during exercise, phagocytosis, inflammation and hypoxic conditions, such as ischemia/reperfusion (22). External stimuli, such as cigarette smoke, environmental pollutants, radiation, drugs, pesticides, chemical solvents and the ozone can also cause the generation of free radicals (22). Oxidative stress was initially introduced in 1985 and represents the imbalance between free reactive oxygen species (ROS) and the ability of a biological system to counteract their production and repair provoked damage $(23,24)$. Thereafter it has been defined as the disruption of the anti/pro-oxidant equilibrium of an organism that leads to the destruction of biomolecules, such as proteins, lipids and DNA (25). At the organ level, oxidative stress has been directly implicated in the development of several pathophysiological conditions, with the list of disorders and diseases constantly increasing to date $(26,27)$. More specifically, oxidative stress has been linked as causative or contributing factor in several types of cancer, cardiovascular diseases, neurological disorders (Parkinson's, Alzheimer's, Huntington, bipolar disorder and schizophrenia), autoimmune diseases (rheumatoid arthritis), metabolic disorders (diabetes), chronic fatigue syndrome and even AIDS, hepatitis, aging and fragile $\mathrm{X}$ chromosome syndrome (27-29).

Antioxidants counteract the produced free radicals when they are present at very low concentrations compared to those of an oxidizable substrate and delay or prevent the oxidation of that substrate. They successfully neutralize free radicals via borrowing them a free electron without becoming toxic themselves. There are two major types of antioxidant mechanisms: The enzymatic and non-enzymatic (26). The enzymatic branch contains endogenous proteins, such as superoxide dismutase (SOD), catalase (CAT), glutathione peroxidase $(\mathrm{GPX})$ and glutathione reductase $(\mathrm{GR})$. The non-enzymatic branch contains molecules other than proteins that can scavenge radical molecules, such as vitamin $\mathrm{E}$, vitamin $\mathrm{C}, \beta$-carotene, coenzyme Q-10, selenium and several bioactive phytochemicals. The latter is used to describe substances of plant origin present in food, with polyphenols to be the major bioactive/phytochemical compounds found in foods, as well as the most extensively studied ones for their multi-dimensional biological properties $(30,31)$. Epidemiological studies have associated the consumption of fruits, vegetables and herbs with beneficial effects on chronic diseases, which have been attributed to their phytochemical properties $(32,33)$. The term 'polyphenols' refers to a multitude of organic compounds, with one or more hydroxyls directly attached to one or more aromatic rings. Their protective antioxidant capacity derives from the ability of the phenolic groups to act as strong electron receptors, forming stable phenoxyl radicals.

\section{In vitro cell-free system measurements}

Measurements that signify extract or compound bioactivity in in vitro cell-free systems require reproducibility and comparability. For that, a specific unit is used to showcase the results and a standard that can be used from different laboratories globally is proposed. In particular, in all methodologies that are presented below, apart from the Folin-Ciocalteu (FC) method and reducing power assay, $\mathrm{IC}_{50}$ represents the concentration of the tested sample required for inhibiting the $50 \%$ of the corresponding free radical. Obviously, the lower the $\mathrm{IC}_{50}$ value, the greater the antioxidant capacity of the sample tested. For the same purpose, as regards the reducing power assay that will be explained further below, an $\mathrm{AU}_{0.5}$ value is estimated, representing the concentration of the tested sample required for achieving an absorbance value of 0.5 . Moreover, for the determination of total phenolic content with the FC method, the analysis readout is expressed in $\mathrm{mg} \mathrm{GAE} / \mathrm{g}$ dry weight of tested sample. Additionally, a known antioxidant compound can serve as a standard, thus comparing its antioxidant activity with that of the tested sample. In this regard, vitamin $\mathrm{C}$, a hydrophilic molecule that exhibits antioxidant activities through the neutralization of reactive species and the regeneration of other endogenous antioxidants can be used. The selection of vitamin $\mathrm{C}$ as a method standard lies also in its abundant presence in natural foods, including honey (34), 


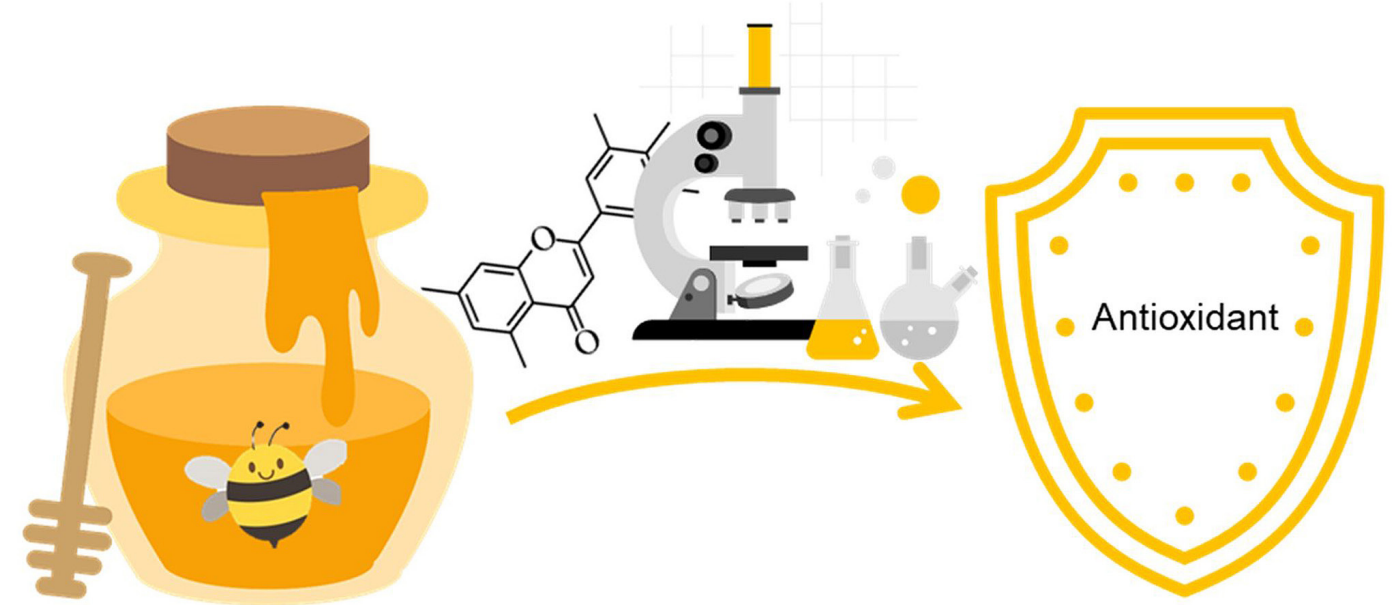

Figure 1. Illustration summary that depicts the scope of the review article.

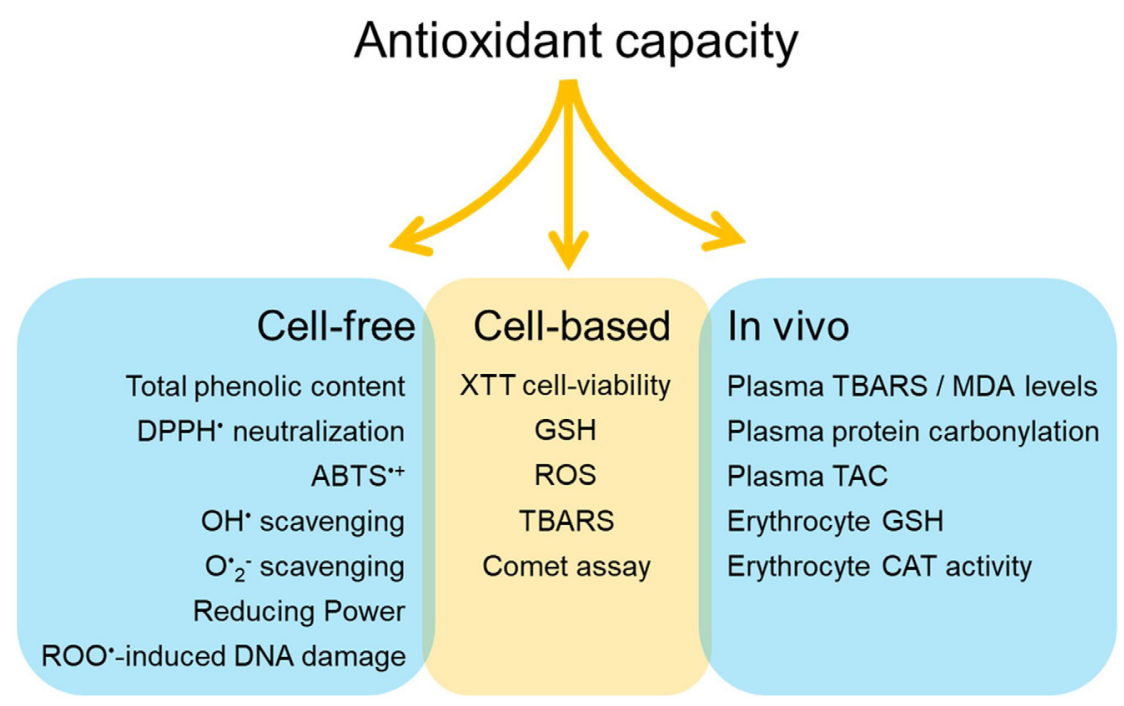

Figure. 2. Proposed methodology to assess antioxidant capacity of different honey samples in three different levels; in vitro cell-free or cell-based system and in vivo system.

as well as in its fundamental roles for various endogenous processes $(35,36)$.

The proposed methods can be applied for the evaluation of both lipophilic and hydrophilic antioxidants in the tested nutritional products providing a complete set of screening techniques. It has been proposed that the assays that involve peroxyl radical scavenging should be taken seriously into account as it is the most dominant in biological setups (37). Although 2,2'-azino-bis(3-ethylbenzothiazoline-6-sulfonic acid (ABTS) and 2,2-diphenyl-1-picrylhydrazyl (DPPH) assays rely on slow reactions that are sensitive to ascorbic acid, uric acid and polyphenols, enabling secondary reactions that are likely to occur and yield false-positive results (38), they are preferable since they are easy to use and fast. Due to their drawbacks, they cannot be considered as stand-alone techniques, but are used for preliminary screening purposes. Whenever it is possible, they should be used providing also kinetic data, i.e., by monitoring the reaction products over time instead of performing end-point measurements, that might provide enriched data such rate constants that can serve as a reaction indicator (39). Finally, it is worth mentioning that none of the cell-free assays that are described below can be expected to provide biological activity of antioxidants. Therefore, the use of cell-based methods should be taken into consideration, as critical aspects of their use could bring valuable complementary information for the activity of our tested samples in simplified biological systems such as cell cultures.

FC method for the evaluation of the total phenolic content $(T P C)$. The FC assay is not specific for particular groups of phenolic compounds but is used for the determination of their total concentration in various extracts $(40,41)$. Typically, the TPC is determined via a gallic acid (GA) standard curve $(42,43)$. Gao et al (44) suggested that the main polyphenolic component of each food extract may be used as the assay standard. For example, the use of epigallocatechin as a standard is more preferable than GA, when TPC is measured in tea extracts. Generally, catechin, epigallocatechin and quercetin are used as commercial standards. However, due to the laborious nature of the identification of the main polyphenol, GA is widely used 
for food extracts, including honey $(45,46)$, since it represents a stable, simple and inexpensive commercial standard (44).

The FC method is proposed to evaluate the TPC of each honey batch derived from different sources of flower nectar. The FC method is a colorimetric assay and is based on a redox reaction of a specific reagent (FC reagent), a solution of phosphotungistic-phosphomolybdenium heteropolymeric acids (47). Phenolic ions in plant extracts are oxidized in alkaline FC solution while heteropolymeric acids are reduced as shown on the following chemical reaction: $\mathrm{P}_{2} \mathrm{~W}_{18} \mathrm{O}_{62}{ }^{-7} \rightarrow \mathrm{H}_{4} \mathrm{P}_{2} \mathrm{~W}_{18} \mathrm{O}_{62}{ }^{-8}$, $\mathrm{H}_{2} \mathrm{P}_{2} \mathrm{Mo}_{18} \mathrm{O}_{62}{ }^{-6} \rightarrow \mathrm{H}_{6} \mathrm{P}_{2} \mathrm{Mo}_{18} \mathrm{O}_{62}{ }^{-7}$.

The reaction forms a blue chromophore that is a molybdenum-tungsten (Mo-W) complex that can be easily read spectrophotometrically at $765 \mathrm{~nm}$ (47). FC reagent alkalinity is regulated by saturated $\mathrm{Na}_{2} \mathrm{CO}_{3}$ solution and is a prerequisite for the determination of the phenolic ions without affecting FC reagent stability or reaction's end-product. TPC can also be used to determine the level of adulteration (19). Heating and dilution processes with sugar syrup that is used during adulteration has a reducing effect in TCP. Thereafter, a marked decrease in TPC may indicate impurity.

$\mathrm{DPPH}^{\bullet}$ free radical neutralization assay for determination of antioxidant capacity. DPPH free radical neutralization assay for determining the antioxidant capability of a substance was used for the first time by Brand-Williams et al (48). Currently, the method has been evolved and has become one of the most established, yet simple, methods for the preliminary assessment of the antioxidant strength of substances or extracts that contain antioxidant compounds. The assessment is based on the interaction of the substance in question, with the stable free radical DPPH${ }^{*}$. DPPH ${ }^{\bullet}$ free radical can be neutralized by receiving an electron or a hydrogen proton as follows: $\mathrm{DPPH}_{\text {(violet at } 515 \mathrm{~nm})}+\mathrm{ArOH} \rightarrow \mathrm{DPPH}(\mathrm{H})_{\text {(colorless) }}+\mathrm{ArO}^{*}$.

$\mathrm{DPPH}^{\circ}$ is an organic, nitrogen-based radical, that has a purple color and can be easily quantified spectrophotometrically at $517 \mathrm{~nm}$. When a substance that exhibits antioxidant activity is added to a free radical solution, $\mathrm{DPPH}^{\bullet}$ is reduced by the addition of a proton atom and converted into DPPH-H. The latter possess a yellow color and results a reduction in sample optical density. Significant decrease of antioxidant capacity through DPPH${ }^{*}$ readout could also implicate that honey batch underwent adulteration process (19). It is proposed that DPPH and TPC should be measured together in order to strengthen the probability of honey adulteration.

$A B T S^{\bullet+}$ free radical for determination of antioxidant capacity. The mechanistic principle of $\mathrm{ABTS}^{\bullet+}$ free radical technique is similar to the one described with $\mathrm{DPPH}^{*} . \mathrm{ABTS}^{\bullet+}$ free radical can be once again neutralized by the addition of either an electron or a hydrogen proton (38): $\mathrm{ABTS}^{\bullet+}{ }_{\text {(green at } 730 \mathrm{~nm})}+\mathrm{ArOH} \rightarrow$ $\operatorname{ABTS}(\mathrm{H})_{\text {(colourless) }}+\mathrm{ArO}^{*}$.

Unlike DPPH', which already exists as a stable radical, ABTS $^{\cdot+}$ needs to be produced by the oxidation of ABTS initially. Subsequently, formed $\mathrm{ABTS}^{\bullet+}$ free radical reacts with the substance of interest. This technicality occurs to avoid any potential off-site interactions between the antioxidant compound and the oxidative agents used for the oxidation of ABTS. Generally, the oxidation of ABTS occurs either through chemical reactions with various oxidizing reagents, or via enzymes such as peroxidases (49). The $\mathrm{ABTS}^{\bullet+}$ free radical remains stable after its formation, has a green color and can be read with spectrophotometer as the previous read-outs, at $730 \mathrm{~nm}$. Similarly, antioxidant substance donates hydrogen atom into $\mathrm{ABTS}^{\circ+}$ free radical resulting a drop in optical density.

The use of DPPH and ABTS assays will allow for a more representative estimation of the antioxidant capacity of the phenolic compounds that the specimen in question carries. Given the fact that DPPH and ABTS assays use organic (methanol) and water-based solvents, they can detect mainly hydrophobic or both lipophilic and hydrophilic antioxidants respectively (50). Apart from polyphenols, honey also contains proteins that exert antioxidant capacity, such as catalase and glucose oxidase (51); however, their ability to scavenge relies on their enzymatic activity and not via hydrogen atom transfer (HAT) that $\mathrm{DPPH}^{\circ}$ and ABTS rely on.

Hydroxyl radical $\left(\mathrm{OH}^{*}\right)$ scavenging assay for the determination of antioxidant activity. $\mathrm{OH}^{*}$ can cause serious damage to cell biomolecules since it has detrimental effects in biological systems and is considered an extremely harmful compound in free radical pathology. This radical is produced in the vicinity of nucleic acids and causes significant damage if it is not reduced, since it cannot diffuse. It is known to induce several types of damage in DNA and RNA, leading to carcinogenesis, mutagenesis and cytotoxicity (52). The ability of an extract to scavenge the $\mathrm{OH}^{*}$ is directly related to its antioxidant capacity. It was first described in 1997 (53), and it is performed to assess the antioxidant efficacy against natural processed pro-oxidants such as $\mathrm{OH}^{*}$. The method relies on the oxidation of 2-deoxyribose. During the Fenton reaction, $\mathrm{OH}^{\bullet}$ radicals oxidize 2-deoxyribose into malondialdehyde (MDA), leading to a colorimetric outcome and can be measured spectrophotometrically at $520 \mathrm{~nm}$ : 2-deoxyribose $+\mathrm{OH}^{\bullet} \rightarrow$ MDA. The ability of an extract to scavenge hydroxyl radicals is estimated as the rate of inhibition of 2-deoxyribose oxidation by them.

Superoxide $\left(\mathrm{O}_{2}^{-}\right)$radical scavenging assay. Superoxide radical $\left(\mathrm{O}_{2}^{-}\right)$scavenging activity is evaluated by the Gülçin method (54). $\mathrm{O}_{2}^{-}$is able to lead to cell death, and contributes to enzyme inactivation, cell membranes and polysaccharide degradation. It is responsible for the peroxidation of unsaturated fatty acids (55) with some end-products, such as MDA being mutagenic and carcinogenic (56). Furthermore, $\mathrm{O}_{2}^{*}$ - can damage DNA at guanine residues, that causes mutations resulting in cancer and aging (57). $\mathrm{O}_{2}^{-}$radicals are derived from PMS-NADH systems through the oxidation of NADH and can be measured via the reduction of nitro blue tetrazolium (NBT). The $\mathrm{O}_{2}^{-}$reduction swifts yellow color derived from $\mathrm{NBT}^{2+}$ into blue which can be measured spectrophotometrically at $560 \mathrm{~nm}$ : PMS-NADH $+\mathrm{O}_{2}$ $\rightarrow \mathrm{O}_{2}^{\circ} ; \mathrm{O}_{2}^{-}+\mathrm{NBT}^{2+}$ (yellow) $\rightarrow$ formazan/NBT (blue). Substances with antioxidant capacity are able to inhibit NBT formation.

Reducing power assay. Metal ions are necessary in living organisms and play pivotal roles in a wide variety of physiological processes (58). Additionally, they contribute to the generation of ROS, such as hydroxyl radicals through the Fenton reaction. Therefore, the reducing power of a substance is related to the antioxidant capacity and constitutes a reliable 
indicator of it. To determine the reducing capacity, the ability of the samples to reduce $\mathrm{Fe}^{+3}$ into $\mathrm{Fe}^{+2}$ is examined via the reducing power assay according to Yen and Duh (59): $2 \mathrm{Fe}(\mathrm{CN})_{6}{ }^{-3}+$ antioxidant- $\mathrm{H} \rightarrow 2 \mathrm{Fe}(\mathrm{CN})_{6}{ }^{-4}+$ antioxidant $^{-}+\mathrm{H}^{+}$.

This reduction leads to a reaction with ferrocyanide, forming a complex that can be measured spectrophotometrically at $700 \mathrm{~nm}$, with the initial sample yellow color changing to different shades of green and blue, depending on the reducing power efficacy: $4 \mathrm{Fe}^{+3}+3 \mathrm{Fe}(\mathrm{CN})_{6}^{-4}$ (yellow) $\rightarrow \mathrm{Fe}_{4}\left[\mathrm{Fe}(\mathrm{CN})_{6}\right]_{3}$ (Prussian blue) .

The higher the absorption becomes, the greater the reducing power is. Compounds with a reducing power potential indicate that they are electron donors and can reduce oxidized intermediates to act as primary or secondary antioxidant compounds.

Peroxyl radical ( $\left.\mathrm{ROO}^{\circ}\right)$-induced DNA damage. With the aforementioned methods, the scavenging efficacy and reducing power of different honey substrates can be determined spectrophotometrically using technical or natural produced radical agents. The antioxidant capacity of a sample is preferable to be evaluated through a different methodology. For that, the protective action of the honey samples in question against single-strand breaks in plasmid-DNA induced by peroxyl radicals ( $\mathrm{ROO}^{\circ}$ ) was assessed (59-61). The method has been previously described by Priftis et al in 2015 (62). According to the assay, the thermal decomposition of 2,2'-azobis(2-amidinopropane hydrochloride) (AAPH) leads to $\mathrm{ROO}^{\circ}$ generation: $\mathrm{R}-\mathrm{N}=\mathrm{N}-\mathrm{R} \rightarrow 2 \mathrm{R}^{\bullet}+\mathrm{N}_{2} ; \mathrm{R}^{\bullet}+\mathrm{O}_{2} \rightarrow \mathrm{ROO}^{\bullet}$.

Compounds bearing an azo group, such as AAPH, are widely used for the induction of lipid peroxidation in vitro $(63,64)$, as well the previously mentioned single-strand DNA breaks. Since plasmid DNA natively exists in its supercoiled conformation (65), the addition of AAPH to the reaction and the concomitant generation of $\mathrm{ROO}^{\bullet}$ leads to the formation of single-strand breaks. In this way, the plasmid DNA is converted to the open circular conformation, which runs slower than the supercoiled when electrophoresed on agarose gel (Fig. 3). In the presence of an antioxidant compound, ROO are scavenged, single-strand breaks are prevented, and thus plasmid-DNA retains its supercoiled conformation.

\section{In vitro measurements in cell cultures}

Cell-based in vitro methods are performed to bypass the mechanistic limitations of the preliminary screening step of cell-free assays. Cell lines differ from primary cells due to their immortalized cancerous phenotype. Their use in in vitro applications is advantageous as they produce high cell numbers, allowing experimental replications and repetitions. This also facilitates the use of the 'Reduce' principle of the 3Rs concerning the framework for performing more humane animal research. Another positive point is that they generate higher basal levels of ROS (66). ROS physiologically activate molecular pathways that enable cellular growth and replication (67), rendering an ideal platform to examine the antioxidant effect of polyphenolic content. This effect should not be considered one-dimensional by examining a possible ROS decrease, but should involve the assessment of the overall equilibrium between oxidative-antioxidant mechanisms and molecules (68). Although polyphenols affect oxidative and antioxidant molecules, thus altering cancer cell phenotypes

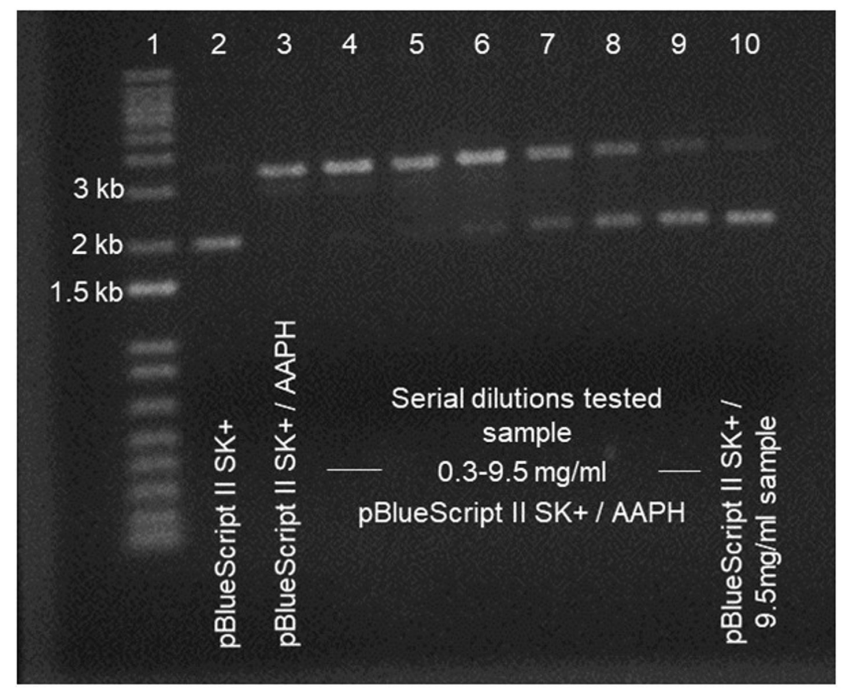

Figure 3. Representative agarose electrophoresis gel after peroxyl radical (ROO')-induced DNA damage. Lane 1, 1 kb Invitrogen DNA ladder; lane 2, pBlueScript II SK(+) DNA; lane 3, pBlueScript II SK (+) with 2'-azobis(2-amidinopropane hydrochloride) (AAPH); lanes 4-9, pBlueScript II SK (+) with 2'-azobis(2-amidinopropane hydrochloride) (AAPH) supplemented with serial dilutions of tested sample (from 0.3 up to $9.5 \mathrm{mg} / \mathrm{ml}$ ); lane 10, pBlueScript II SK (+) with the highest concentration $(9.5 \mathrm{mg} / \mathrm{ml})$ of the tested sample. The respective agarose gel depicts a representative experimental run of the effect of a native flower honey that was conducted in the authors' laboratory.

such as proliferation and migration, the present review focused solely on the antioxidant capacity of polyphenols that are present in foods and more specifically, in honey. Thereafter, additional information concerning further tumorigenic manifestations, pertains the scope of the present review article.

Vitamin C, a well-known water-soluble antioxidant, can serve as an example of poor protection against induced radical damage, localized in the core of a phospholipid bilayer such as cell membranes (69). In contrast to cell-free systems, this experimental level incorporates biological factors such as absorption, distribution and metabolism. Of note, the selection of representative cell-line must answer the biological inquiry and take into consideration critical factors such as growth factors, sensitivity, biological background, availability, handling convenience and the ability to develop data for possible comparative studies (70). A variety of cell-line models have been proposed for specific scientific questions; however, the use of common immortalized cell lines is easier and more applicable (71).

HeLa and HepG2 are two cell lines that can be used. This proposal derives from their long-term and extensive use in research, as well as due to their probable existence in the majority of the most laboratory structures worldwide. More elaborately, HeLa cells are derived from a glandular cervical cancer in 1951 and since then, they have been used and are widely referenced in thousands publications of biological studies that have contributed to a number of medical breakthroughs, from zero gravity effects and polio vaccine development, to AIDS studies and cancer worldwide (72). HepG2 cells, even though they have a cancerous phenotype, they also possess a number of the biochemical and morphological characteristics of primary hepatocytes $(73,74)$, allowing for the study of the hepatoprotective effects and antioxidant properties of natural 
products in a 'platform' that its main function is the detoxification activity. Additionally, HepG2 is the most extensively studied liver cell line mainly due to availability, similarity in the human secreted proteins (75). Furthermore, the importance of glutathione (GSH) in cancer biology followed by the significant abundant levels of glutathione in the hepatocytes, defines HepG2 cells a suitable cell-line to determine ROS and GSH (76), under stress conditions and honey extracts treatments. Although HepG2 cells seem to represent the perfect candidate, an increased catalase expression and asymmetrical cell divisions have led to criticism (70). Moreover, Caco-2 cells could serve as a good alternative cell line, as they ares used to evaluate the bioavailability and metabolic conversion of antioxidants, such as carotenoids and flavonoids, from whole foods (77-79).

Determination of sample concentration through XTT cell-viability assay. Different cell lines are cultured (80-90\% confluency) with their respective medium in 96-well plates for $24 \mathrm{~h}$ at $37^{\circ} \mathrm{C}$ in $5 \% \mathrm{CO}_{2}$. Fresh serum-free medium supplemented with various sample concentrations is placed in cell cultures for a consecutive 24-h incubation under the same conditions. Untreated cells are always used as the respective negative control. Working solution of sodium 3,3'-[1(phenylamino)carb onyl]-3,4-tetrazolium]-3is(4-methoxy-6-nitro) benzene sulfonic acid hydrate, also known as tetrazolium sodium or XTT (80), that contains XTT-labeling reagent and XTT activator (50:1) is added to each well. Following $4 \mathrm{~h}$ of incubation, the optical density is measured at $450 \mathrm{~nm}$ with the background correction at $690 \mathrm{~nm}$. Additional cell-free controls, such as medium supplemented with the samples alone and serum-free medium alone, always should be placed to determine any color change of the media due to the sample content. The absorbance values shown by the tested samples alone must be subtracted from those derived from cell treatment together with the tested samples. The absorbance values of the control and samples are used for calculating the percentage inhibition of cell growth caused by the sample treatment. Following optical density calculations, the effect of the tested sample is expressed as the percentage of cell viability compared to untreated cells. The concentration that allows $>75 \%$ viability is selected for following-up sample redox biomarkers evaluation readouts: XTT tetrazolium + mitochondrial dehydrogenase $\rightarrow$ XTT formazan.

One characteristic indicating that XTT is preferable over MTT assay is the nature of the solvent. XTT is water-soluble and not toxic, while MTT needs to be dissolved in DMSO. Additionally, XTT does not require solubilization prior to quantification, thereby assay time is reduced. Moreover, the sensitivity of the XTT is similar or even superior than MTT reduction assay (81). Notably, XTT assay has been previously performed for determining the cytotoxic concentrations of natural food components, including olive oil (42), dairy products $(82)$, grape $(83,84)$ and coffee (85) extracts to a wide range of cell lines.

Assessment of GSH and ROS levels by flow cytometry. The tripeptide GSH consists of the amino acids cysteine, glycine and glutamic acid, and is a major antioxidant molecule playing an important role in the maintenance of redox homeostasis (86): $2 \mathrm{GSH}+\mathrm{H}_{2} \mathrm{O}_{2} \rightarrow \mathrm{GSSG}+2 \mathrm{H}_{2} \mathrm{O} ; \mathrm{GSSG}+\mathrm{NADPH}$ $+\mathrm{H}^{+} \rightarrow 2 \mathrm{GSH}+\mathrm{NADP}^{+}$.
The assessment of cellular GSH and ROS levels by flow cytometry can be performed as previously described (42). More specifically, cell lines incubated in $25 \mathrm{~cm}^{2}$ flasks following the same confluency as XTT assay, are subjected to 24-h incubation with the selected sample concentration. Following treatment, the cells are washed and resuspended after trypsin $(0.25 \% \mathrm{w} / \mathrm{v})$ application. Subsequently, the cells are washed to remove trypsin and stained with mercury orange $(40 \mu \mathrm{M})$ or 2',7'-dichlorodigydrofluorescein diacetate $\left(\mathrm{H}_{2} \mathrm{DCFDA} ; 10 \mu \mathrm{M}\right)$ for $30 \mathrm{~min}$ in the dark at $37^{\circ} \mathrm{C}$ to determine the GSH and ROS content, respectively. Cells are washed again with PBS to remove the excess dye. Cellular GSH and ROS levels are determined through flow cytometry at 488/580 nm for GSH and 488/530 nm for ROS, respectively. Following flow cytometry forward and side scatter gating, that takes into consideration cellular size and granularity, the mean fluorescence intensity is determined on minimum of 10,000 cells per sample (Fig. 4). Data are presented as the fold change of mean fluorescence intensity in comparison with control experimental group.

Flow cytometry provides high speed analyses and measurements in large cell numbers. Moreover, it enables the non-laborious quantification of fluorescence intensities. A critical aspect is the selection of the appropriate fluorescent dye or probe to assess redox potential. The most commonly used and inexpensive molecular probes for the assessment of cellular oxidative stress is $\mathrm{H}_{2}$ DCFDA (87). Mercury orange is also able to bind with higher affinity to GSH than proteins, giving a degree of specificity $(88,89)$.

Assessment of TBARS by spectrophotometry. Oxidative stress in cells leads to active and unstable lipid peroxides. The decomposition of unstable peroxides derived from polyunsaturated fatty acids (PUFAs) leads mainly to the formation of MDA (90): PUFA $+{ }^{-} \mathrm{OH} \rightarrow$ lipid free radical $+\mathrm{H}_{2} \mathrm{O} ; \mathrm{LFR}+\mathrm{O}_{2} \rightarrow$ lipid peroxyl radical $\rightarrow$ lipid hydroperoxide $\rightarrow$ MDA. Thiobarbituric acid (TBA) reactive substances (TBARS) are one of the most frequently used methods for lipid peroxidation induced by the reactivity of free radicals, since they spectrophotometrically detect MDA levels (91). This method is based on a condensation reaction of two molecules of TBA with one molecule of MDA and absorbance is recorded at $532 \mathrm{~nm}$ (92): $\mathrm{MDA}+2 \mathrm{TBA} \rightarrow \mathrm{MDA}^{-\mathrm{TBA}_{2}}$ adduct.

Cell lines treated with known effective concentrations are spinned down and lysed with whole cell lysis buffer [Tris $(20 \mathrm{mM}), \mathrm{NaCl}(150 \mathrm{mM}), 1 \%$ Nonidet P40, pH 7.5], containing protease inhibitors (Complete $^{\mathrm{TM}}$ mini protease inhibitors; Roche Diagnostics). Following a 20-min incubation on ice and centrifugation $\left(16,250 \mathrm{x} \mathrm{g}, 20 \mathrm{~min}, 4^{\circ} \mathrm{C}\right)$ the supernatant that is the crude cell lysate is collected and used for the determination of TBARS. At first, an amount of the cell lysate is incubated for $10 \mathrm{~min}$ in 1:1 mix of trichloroacetic acid (TCA, 35\%) and Tris-HCl buffer (200 mM, pH 7.4) to induce protein precipitation that will easily enable the reaction of TBA with lipid macromolecules. Subsequently, $\mathrm{Na}_{2} \mathrm{SO}_{4}(2 \mathrm{M})$ and TBA $(55 \mathrm{mM})$ mix solution are added, followed by incubation at $95^{\circ} \mathrm{C}$ for $45 \mathrm{~min}$ to yield the complex with MDA. Following a follow-up precipitation with $70 \%$ TCA and centrifugation $\left(11,200 \times \mathrm{g}, 3 \mathrm{~min}, 25^{\circ} \mathrm{C}\right)$, the optical density is monitored at $530 \mathrm{~nm}$. The TBARS concentration determination is based on 

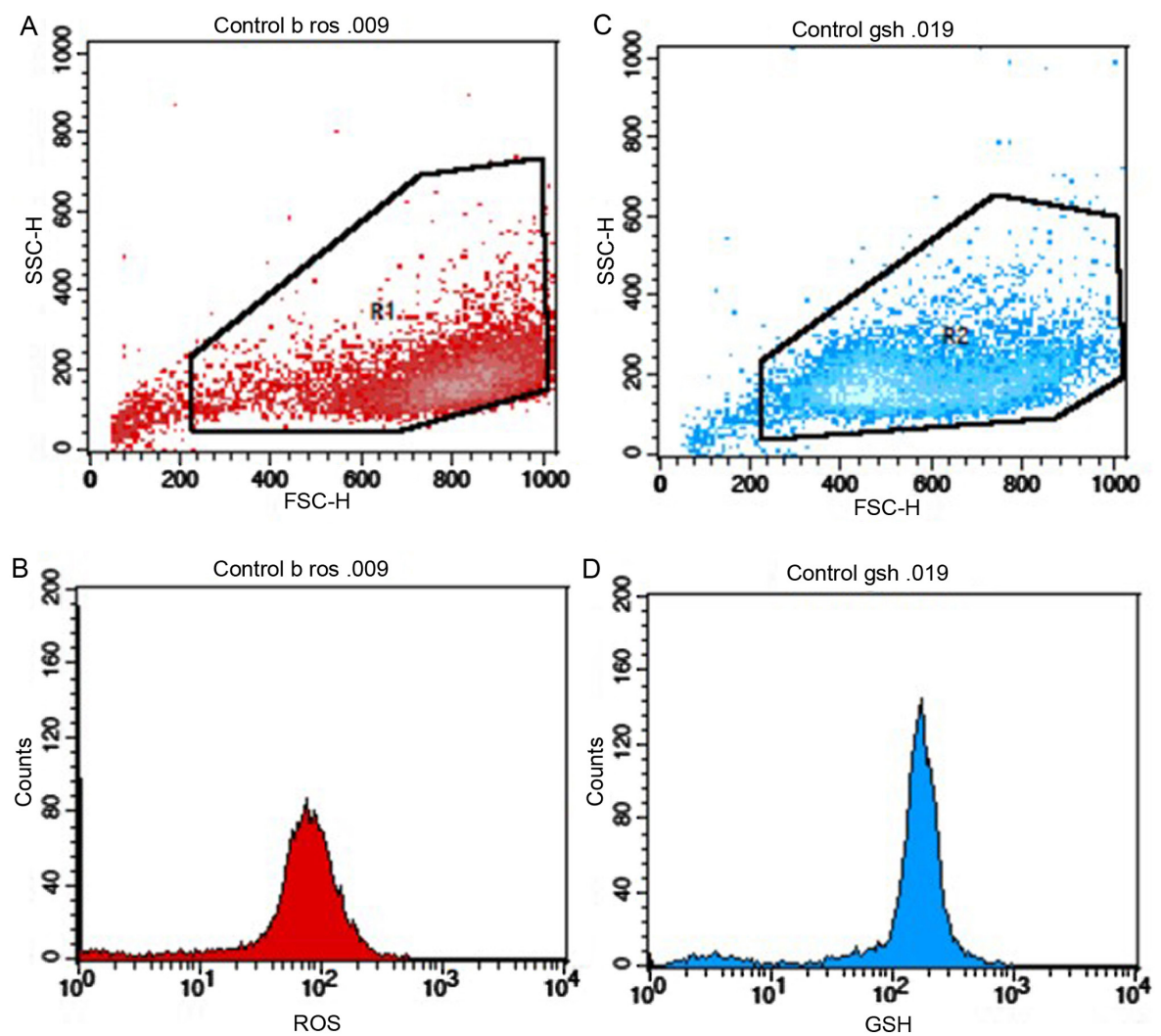

Figure 4. Representative (A and C) scatter plots and (B and D) histograms from flow cytometric analysis for the determination of (A and B, red color) ROS levels and (C and D, blue color) GSH. In scatter plots, gating is performed (R1 or R2) according to cell size and granularity. Subsequently, respective fluorescence is determined in gated cells. ROS, reactive oxygen species; GSH, glutathione. The respective flow cytometry plots depict representative experimental runs of untreated HeLa cells that was conducted in the authors' laboratory.
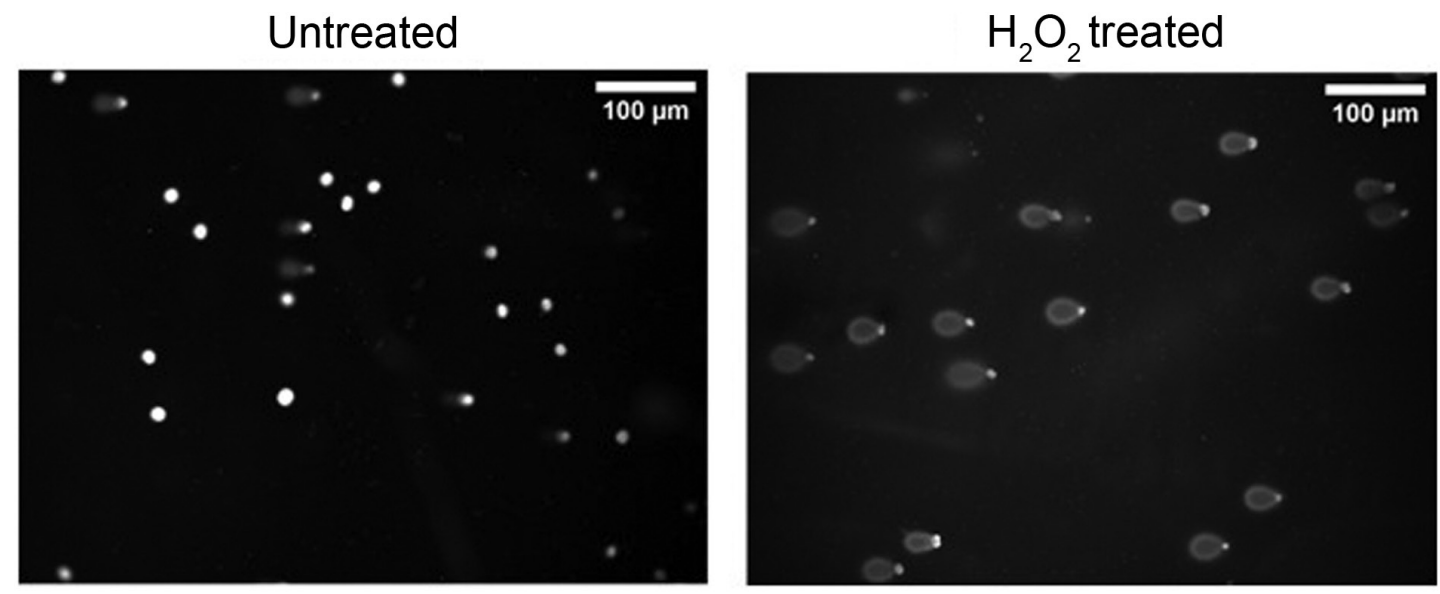

Figure 5. Representative image of Comet assay performed in EA.hy926 cells treated with or without $\mathrm{H}_{2} \mathrm{O}_{2}(200 \mu \mathrm{M})$. The respective microscopy images derived from a representative experimental run in EA.hy926 cells that was conducted in the authors' laboratory.

the molar extinction coefficient of MDA $(156,000 \mathrm{~mol} / \mathrm{l})$ and is normalized to total protein concentration of cell lysate and presented as nmol TBARS per mg protein of total cell extract.

Comet assay. This fluorescence-based methodology was originally proposed by Singh et al (93). The Comet assay method relies on the ability of smaller DNA fragments to migrate more rapidly in an electric field than larger molecules. The method is performed in cells that are encapsulated in agarose gel and lysed with alkaline solution that is able to denature DNA. Thereafter, cells are placed on agarose film in microscope slide and following electrophoresis, cell-DNA fragments are visualized through fluorescent microscopy with the use of intercalating dyes such as SYBR-Green. Undegraded DNA appears solid in the nuclear area, whereas fragmented DNA-induced by an oxidative agent move faster, appears as a 'comet tail' (Fig. 5). This technique allows for the verification of the antioxidant ability of different honey batches against DNA degradation that was initially assessed with ROO $^{*}$-induced DNA damage. DNA degradation can 
be quantified through the determination of the displacement between the genetic material of the nucleus ('comet head') and the 'comet tail'. Tail DNA\% and tail moment are the main analysis readouts that are usually presented. Tail moment represents the induced DNA degradation, integrating both genetic material displacement and relative amount of DNA in the tail: Tail DNA\% = tail DNA fluorescence intensity/cell (nucleus + tail) DNA fluorescence intensity. Tail moment $=$ tail DNA\% x tail length. Both parameters should be analyzed for at least 50 cells per treatment and mean values should be presented.

\section{In vivo measurements}

The previous techniques performed in both in vitro cell-free or cell systems provide strong evidence for the antioxidant and reductive potential of each agricultural product or food; however, their impact on humans needs to be examined in order to discuss with clarity their beneficial effects on human health. This experimental level is of vital importance in the proposed protocol scheme, as the antioxidant capacity of foods is influenced by various parameters in vivo, such as gut absorption, metabolism, bioavailability and the presence of other compounds that exert reveal antioxidant activity (94). Therefore, it is of utmost importance that the preliminary screening performed with in vitro assays, always be complemented by their in vivo efficacy (95), since the use of in vivo assays offers highly relevant information for the performance and biological potential of antioxidants. The redox biomarkers proposed are cost-effective, reasonably stable, and can be easily and accurately measured spectrophotometrically (96-99). Oxidative stress has been implicated in the development of numerous chronic or acute pathophysiologies and disease; however, the cause-effect association is under perpetual investigation (100). The clinical significance of biomarkers of oxidative stress in humans must derive from a critical analysis of the markers that should give an overall index of redox status in particular conditions (101).

To determine the effects of honey or other agricultural goods, redox status parameters in human volunteers can be assessed at different time points. Several experimental plans can be followed, always depending on volunteer availability and tested products. A crossover study is considered the optimal choice as the influence of confounding covariates is reduced since every volunteer serves as its own control (102). A different approach is a longitudinal study in which redox status parameters in volunteers are evaluated before, during and after treatment (103). Peripheral blood from volunteers is fractionated and plasma with cellular pellet is used for the determination of different parameters. Red blood cell lysate derives from the osmotic lysis of the cellular pellet with distilled water $(1: 1 \mathrm{v} / \mathrm{v})$. Following centrifugation, the erythrocyte lysate is used to determine the GSH concentration and catalase activity (99). Additionally, hemoglobin levels are determined using the hemiglobincyanide (cynamethemoglobin) method in order to serve as normalization factor in GSH and CAT measurements.

Evaluation of lipid peroxidation levels through MDA determination. MDA levels, constituting products of lipid peroxidation, are assessed in plasma samples via two different methods. Initially, they can be quantified performing TBARS assay and the use of a spectrophotometer as mentioned in the in vitro section or using high performance liquid chromatography (HPLC). More specifically, if HPLC is available, MDA quantification is relatively more reliable when it is assessed fluorimetrically (104). Data are usually presented as nmol/lit of plasma.

Evaluation of protein carbonyls in plasma. Proteins are susceptible to oxidative damage with protein carbonyls (PC) to serve as generic markers of oxidation and a biomarker of oxidative stress (105). This assay allows the quantification of the PC content due to the ability of 2,4-dinitrophenylhydrazine (DNPH) to react with protein carbonyls, yielding 2,4-dinitrophenylhydrazone (DNP-hydrazone) as a product. Carbonyl groups (aldehydes and ketones) are mainly formed in proline, lysine and threonine amino acids of proteins and they are preferable markers due to their stable moieties (106). Hydrazones can be easily quantified using spectrophotometer at $375 \mathrm{~nm}$. Data are usually presented as $\mathrm{nmol} / \mathrm{ml}$ of plasma.

Total antioxidant capacity (TAC) determination in plasma. The determination of TAC is based on the method descirbed by Janaszewska and Bartosz (107). TAC refers to the ability of the plasma antioxidant components to scavenge free radicals, while each component contributes to the antioxidant capacity of plasma differently. The principle of the assay is based on the reaction of plasma antioxidant components with the commercial free radical $\mathrm{DPPH}^{\circ}$. In the presence of an antioxidant molecule, $\mathrm{DPPH}^{\bullet}$ is reduced to the corresponding hydrazine, leading to a decrease in optical density at $520 \mathrm{~nm}$. Data are usually presented as nmol DPPH/ml of plasma.

Reduced GSH determination in red blood cell lysates. The GSH concentration is determined as previously described (108). The GSH concentration present in red blood cell lysate (RBCL) is determined using a spectrophotometer with the use of 5,5-dithio-bis-(2-nitrobenzoic acid) (DTNB). GSH is oxidized by the DTNB which results into 2-nitro-5-thiobenzoic acid (TNB), a colored product with absorption at $412 \mathrm{~nm}$. Data are usually presented as $\mathrm{mmol} / \mathrm{gr}$ hemoglobin.

Catalase (CAT) activity determination in red blood cell lysates. CAT activity is determined based on the method described by Aebi (109). CAT is an antioxidant enzyme catalyzing the decomposition of the excess amounts of hydrogen peroxide $\left(\mathrm{H}_{2} \mathrm{O}_{2}\right)$ to water and oxygen, thus preventing from its conversion to the detrimental hydroxyl radicals (110). $\mathrm{H}_{2} \mathrm{O}_{2}$, is added to the erythrocyte lysate containing CAT and its decomposition is monitored through the decrease in optical density at $240 \mathrm{~nm}$. Data are usually presented as units/gr hemoglobin.

\section{Conclusion and future perspectives}

A perpetual debate in the scientific community is the discovery of mechanisms and tools that will inhibit cellular oxidative processes and at the same time contribute to health promotion. Biofunctional foods possess a special position in this discussion, since they can be easily integrated in our daily routine, 
exerting their beneficial properties. Therefore, research on the improvement of wellness has extensively increased over the past decades, satisfying in this manner, the increasing demands of the consumer for a balanced lifestyle (7,111-114).

Although the use of honey has been associated since antiquity with the prevention of a number of diseases that implicate oxidative stress $(115,116)$, only recently, several studies have begun to document the beneficial biofunctional properties of honey (116-120), providing a holistic approach for its bioactivity. The present review article brings forward a comprehensive strategy for the evaluation of the redox-related effects of honey. The proposed approach is expected to set a basis in the field of functional nutrition, ensuring comparability and reproducibility among future studies that will determine unknown properties of different honey varieties or even other agricultural goods in in vitro and in vivo systems.

\section{Acknowledgements}

Not applicable.

\section{Funding}

No funding was received.

\section{Availability of data and materials}

Not applicable.

\section{Authors' contributions}

IDK, ZS and DK were involved in the conceptualization of the study. IDK, ZS, FT, SM, PV, EV, AP, KT and CA were involved in the writing of the draft of the manuscript. IDK and DK were involved the editing and reviewing of the study. IDK and DK confirm the authenticity of all the raw data. All authors read and approved the final manuscript.

\section{Ethics approval and consent to participate}

Not applicable.

\section{Patient consent for publication}

Not applicable.

\section{Competing interests}

The authors declare that they have no competing interests.

\section{References}

1. Olson DM and Dinerstein E: The Global 200: Priority ecoregions for global conservation. JSTOR 89: 199-224.

2. Medail F and Quezel P: Hot-spots analysis for conservation of plant biodiversity in the mediterranean basin. Ann Mo Bot Gard 84: 112-127, 1997

3. Myers N, Mittermeier RA, Mittermeier CG, da Fonseca GA and Kent J: Biodiversity hotspots for conservation priorities. Nature 403: 853-858, 2000.

4. Georghiou K and Delipetrou P: Patterns and traits of the endemic plants of Greece. Bot J Linn Soc 162: 130-422, 2010.
5. Djoussé L, Ellison RC, Beiser A, Scaramucci A, D'Agostino RB and Wolf PA: Alcohol consumption and risk of ischemic stroke: The Framingham Study. Stroke 33: 907-912, 2002.

6. Lucas DL, Brown RA, Wassef M and Giles TD: Alcohol and the cardiovascular system: Research challenges and opportunities. J Am Coll Cardiol 45: 1916-1924, 2005.

7. Ferrières J: The French paradox: Lessons for other countries. Heart 90: 107-111, 2004.

8. Vidavalur R, Otani H, Singal PK and Maulik N: Significance of wine and resveratrol in cardiovascular disease: French paradox revisited. Exp Clin Cardiol 11: 217-225, 2006.

9. Catalgol B, Batirel S, Taga Y and Ozer NK: Resveratrol: French paradox revisited. Front Pharmacol 3: 141, 2012

10. Catalgol B and Ozer NK: Protective effects of vitamin E against hypercholesterolemia-induced age-related diseases. Genes Nutr 7: 91-98, 2012.

11. Bueno-Costa FM, Zambiazi RC, Bohmer BW, Chaves FC, Silva WP, Zanusso JT and Dutra I: Antibacterial and antioxidant activity of honeys from the state of Rio Grande do Sul, Brazil. Lebensm Wiss Technol 65: 333-340, 2016.

12. Al-Waili NS: Natural honey lowers plasma glucose, C-reactive protein, homocysteine, and blood lipids in healthy, diabetic, and hyperlipidemic subjects: Comparison with dextrose and sucrose. J Med Food 7: 100-107, 2004.

13. Othman Z, Zakaria R, Hussain NHN, Hassan A, Shafin N, Al-Rahbi B and Ahmad AH: Potential role of honey in learning and memory. Med Sci (Basel) 3: 3-15, 2015.

14. Al-Himyari FA: P1-241: The use of honey as a natural preventive therapy of cognitive decline and dementia in the middle east. Alzheimers Dement 5: 247-P247, 2009.

15. Erejuwa OO, Sulaiman SA, Wahab MS, Sirajudeen KN, Salleh MS and Gurtu S: Antioxidant protection of Malaysian tualang honey in pancreas of normal and streptozotocin-induced diabetic rats. Ann Endocrinol (Paris) 71: 291-296, 2010.

16. Kishore RK, Halim AS, Syazana MS and Sirajudeen KN: Tualang honey has higher phenolic content and greater radical scavenging activity compared with other honey sources. Nutr Res 31: 322-325, 2011.

17. Viuda-Martos M, Ruiz-Navajas Y, Fernández-López J and Pérez-Alvarez JA: Functional properties of honey, propolis, and royal jelly. J Food Sci 73: R117-R124, 2008.

18. Carroll MJ, Brown N, Goodall C, Downs AM, Sheenan TH and Anderson KE: Honey bees preferentially consume freshly-stored pollen. PLoS One 12: e0175933, 2017.

19. Nisbet C, Kazak F and Ardalı Y: Determination of quality criteria that allow differentiation between honey adulterated with sugar and pure honey. Biol Trace Elem Res 186: 288-293, 2018.

20. Tosti V, Bertozzi B and Fontana L: Health benefits of the mediterranean diet: Metabolic and molecular mechanisms. J Gerontol A Biol Sci Med Sci 73: 318-326, 2018.

21. Dröge W: Free radicals in the physiological control of cell function. Physiol Rev 82: 47-95, 2002.

22. Pham-Huy LA, He H and Pham-Huy C: Free radicals, antioxidants in disease and health. Int J Biomed Sci 4: 89-96, 2008.

23. Cadenas E and Sies H: Oxidative stress: Excited oxygen species and enzyme activity. Adv Enzyme Regul 23: 217-237, 1985.

24. Sies H and Cadenas E: Oxidative stress: Damage to intact cells and organs. Philos Trans R Soc Lond B Biol Sci 311: 617-631, 1985.

25. Sies H: Oxidative stress: A concept in redox biology and medicine. Redox Biol 4: 180-183, 2015.

26. Halliwell B: The wanderings of a free radical. Free Radic Biol Med 46: 531-542, 2009.

27. Kruk J, Aboul-Enein HY, Kładna A and Bowser JE: Oxidative stress in biological systems and its relation with pathophysiological functions: The effect of physical activity on cellular redox homeostasis. Free Radic Res 53: 497-521, 2019.

28. Cross CE, Halliwell B, Borish ET, Pryor WA, Ames BN, Saul RL, McCord JM and Harman D: Oxygen radicals and human disease. Ann Intern Med 107: 526-545, 1987

29. Cooke MS, Evans MD, Dizdaroglu M and Lunec J: Oxidative DNA damage: Mechanisms, mutation, and disease. FASEB J 17: 1195-1214, 2003

30. Abbas M, Saeed F, Anjum FM, Afzaal M, Tufail T, Bashir MS, Ishtiaq A, Hussain S and Suleria HA: Natural polyphenols: An overview. Int J Food Prop 20: 1689-1699, 2017.

31. Belščak-Cvitanović A, Durgo K, Huđek A, Bačun-Družina V and Komes D: Overview of polyphenols and their properties. In: Polyphenols: Properties, Recovery, and Applications. Galanakis CM (ed). Woodhead Publishing, pp3-44, 2018. 
32. Costa C, Tsatsakis A, Mamoulakis C, Teodoro M, Briguglio G, Caruso E, Tsoukalas D, Margina D, Dardiotis E, Kouretas D, et al: Current evidence on the effect of dietary polyphenols intake on chronic diseases. Food Chem Toxicol 110: 286-299, 2017.

33. Shahidi F and Yeo J: Bioactivities of phenolics by focusing on suppression of chronic diseases: A Review. Int J Mol Sci 19: 19, 2018.

34. Ciulu M, Solinas S, Floris I, Panzanelli A, Pilo MI, Piu PC, Spano N and Sanna G: RP-HPLC determination of water-soluble vitamins in honey. Talanta 83: 924-929, 2011

35. Padayatty SJ and Levine M: Vitamin C: The known and the unknown and Goldilocks. Oral Dis 22: 463-493, 2016.

36. Grosso G, Bei R, Mistretta A, Marventano S, Calabrese G, Masuelli L, Giganti MG, Modesti A, Galvano F and Gazzolo D: Effects of vitamin $\mathrm{C}$ on health: A review of evidence. Front Biosci 18: 1017-1029, 2013.

37. Pisoschi AM, Pop A, Cimpeanu C and Predoi G: Antioxidant capacity determination in plants and plant-derived products: A review. Oxid Med Cell Longev 2016: 9130976, 2016.

38. Prior RL, Wu X and Schaich K: Standardized methods for the determination of antioxidant capacity and phenolics in foods and dietary supplements. J Agric Food Chem 53: 4290-4302, 2005.

39. Amorati $\mathrm{R}$ and Valgimigli L: Advantages and limitations of common testing methods for antioxidants. Free Radic Res 49: 633-649, 2015

40. Granato D, Santos JS, Maciel LG and Nunes DS: Chemical perspective and criticism on selected analytical methods used to estimate the total content of phenolic compounds in food matrices. Trends Analyt Chem 80: 266-279, 2016.

41. Blainski A, Lopes GC and de Mello JC: Application and analysis of the folin ciocalteu method for the determination of the total phenolic content from Limonium brasiliense L. Molecules 18: 6852-6865, 2013.

42. Kouka P, Priftis A, Stagos D, Angelis A, Stathopoulos P, Xinos N, Skaltsounis AL, Mamoulakis C, Tsatsakis AM, Spandidos DA, et al: Assessment of the antioxidant activity of an olive oil total polyphenolic fraction and hydroxytyrosol from a Greek Olea europea variety in endothelial cells and myoblasts. Int J Mol Med 40: 703-712, 2017.

43. Kouka P, Tekos F, Valta K, Mavros P, Veskoukis AS, Angelis A, Skaltsounis AL and Kouretas D: Olive tree blossom polyphenolic extracts exert antioxidant and antimutagenic activities in vitro and in various cell lines. Oncol Rep 42: 2814-2825, 2019.

44. Gao MR, Xu QD, He Q, Sun Q and Zeng WC: A theoretical and experimental study: The influence of different standards on the determination of total phenol content in the Folin-Ciocalteu assay. J Food Meas Charact 13: 1349-1356, 2019.

45. Bertoncelj J, Doberšek U, Jamnik M and Golob T: Evaluation of the phenolic content, antioxidant activity and colour of Slovenian honey. Food Chem 105: 822-828, 2007.

46. Pontis JA, Costa LA, Silva SJ and Flach A: Color, phenolic and flavonoid content, and antioxidant activity of honey from Roraima, Brazil. Food Sci Technol (Campinas) 34: 69-73, 2014.

47. Singleton VL, Orthofer R and Lamuela-Raventós RM: Analysis of total phenols and other oxidation substrates and antioxidants by means of folin-ciocalteu reagent. Methods in Enzymology Academic Press, pp152-178, 1999.

48. Brand-Williams W, Cuvelier ME and Berset C: Use of a free radical method to evaluate antioxidant activity. Lebensm Wiss Technol 28: 25-30, 1995.

49. Arnao MB, Cano A, Alcolea JF and Acosta M: Estimation of free radical-quenching activity of leaf pigment extracts. Phytochem Anal 12: 138-143, 2001.

50. Kim DO, Lee KW, Lee HJ and Lee CY: Vitamin C equivalent antioxidant capacity (VCEAC) of phenolic phytochemicals J Agric Food Chem 50: 3713-3717, 2002.

51. Fahey JW and Stephenson KK: Pinostrobin from honey and Thai ginger (Boesenbergia pandurata): A potent flavonoid inducer of mammalian phase 2 chemoprotective and antioxidant enzymes J Agric Food Chem 50: 7472-7476, 2002.

52. Barciszewski J, Barciszewska MZ, Siboska G, Rattan SI and Clark BF: Some unusual nucleic acid bases are products of hydroxyl radical oxidation of DNA and RNA. Mol Biol Rep 26: 231-238, 1999

53. Chung SK, Osawa T and Kawakishi S: Hydroxyl radical-scavenging effects of spices and scavengers from brown mustard (Brassica nigra). Biosci Biotechnol Biochem 61: 118-123, 1997.

54. Gülçin I, Küfrevioglu OI, Oktay M and Büyükokuroglu ME: Antioxidant, antimicrobial, antiulcer and analgesic activities of nettle (Urtica dioica L.). J Ethnopharmacol 90: 205-215, 2004.
55. Nair U, Bartsch $\mathrm{H}$ and Nair J: Lipid peroxidation-induced DNA damage in cancer-prone inflammatory diseases: A review of published adduct types and levels in humans. Free Radic Biol Med 43: 1109-1120, 2007

56. Niedernhofer LJ, Daniels JS, Rouzer CA, Greene RE and Marnett LJ: Malondialdehyde, a product of lipid peroxidation, is mutagenic in human cells. J Biol Chem 278: 31426-31433, 2003.

57. Cadet J, Douki T, Gasparutto D and Ravanat JL: Oxidative damage to DNA: Formation, measurement and biochemical features. Mutat Res 531: 5-23, 2003.

58. Kontoghiorghes GJ and Kontoghiorghe $\mathrm{CN}$ : Iron and chelation in biochemistry and medicine: New approaches to controlling iron metabolism and treating related diseases. Cells 9: 9,2020.

59. Yen GC and Duh PD: Scavenging effect of methanolic extracts of peanut hulls on free-radical and active-oxygen species. J Agric Food Chem 42: 629-632, 1994.

60. Stagos D, Balabanos D, Savva S, Skaperda Z, Priftis A, Kerasioti E, Mikropoulou EV, Vougogiannopoulou K, Mitakou S, Halabalaki M, et al: Extracts from the Mediterranean food Plants Carthamus lanatus, Cichorium intybus, and Cichorium spinosum enhanced GSH levels and increased Nrf2 expression in human endothelial cells. Oxid Med Cell Longev 2018: 6594101, 2018.

61. Kouka P, Tsakiri G, Tzortzi D, Dimopoulou S, Sarikaki G, Stathopoulos P, Veskoukis AS, Halabalaki M, Skaltsounis AL and Kouretas D: The polyphenolic composition of extracts derived from different greek extra virgin olive oils is correlated with their antioxidant potency. Oxid Med Cell Longev 2019: 1870965, 2019.

62. Priftis A, Stagos D, Konstantinopoulos K, Tsitsimpikou C, Spandidos DA, Tsatsakis AM, Tzatzarakis MN and Kouretas D: Comparison of antioxidant activity between green and roasted coffee beans using molecular methods. Mol Med Rep 12: 7293-7302, 2015

63. Morita M, Naito Y, Yoshikawa T and Niki E: Plasma lipid oxidation induced by peroxynitrite, hypochlorite, lipoxygenase and peroxyl radicals and its inhibition by antioxidants as assessed by diphenyl-1-pyrenylphosphine. Redox Biol 8: 127-135, 2016.

64. Saito K, Matsuoka Y and Yamada KI: Reaction targets of antioxidants in azo-initiator or lipid hydroperoxide induced lipid peroxidation. Free Radic Res 54: 301-310, 2020.

65. Higgins NP and Vologodskii AV: Topological behavior of plasmid DNA. Microbiol Spectr 3: 3, 2015.

66. Szatrowski TP and Nathan CF: Production of large amounts of hydrogen peroxide by human tumor cells. Cancer Res 51 794-798, 1991

67. Mittler R: ROS are good. Trends Plant Sci 22: 11-19, 2017.

68. Poljsak B, Šuput D and Milisav I: Achieving the balance between ROS and antioxidants: When to use the synthetic antioxidants. Oxid Med Cell Longev 2013: 956792, 2013

69. Doba T, Burton GW and Ingold KU: Antioxidant and co-antioxidant activity of vitamin $C$. The effect of vitamin $C$, either alone or in the presence of vitamin $\mathrm{E}$ or a water-soluble vitamin $\mathrm{E}$ analogue, upon the peroxidation of aqueous multilamellar phospholipid liposomes. Biochim Biophys Acta 835: 298-303, 1985.

70. Cheli F and Baldi A: Nutrition-based health: Cell-based bioassays for food antioxidant activity evaluation. J Food Sci 76: R197-R205, 2011.

71. Liu RH and Finley J: Potential cell culture models for antioxidant research. J Agric Food Chem 53: 4311-4314, 2005.

72. Lyapun IN, Andryukov BG and Bynina MP: HeLa cell culture: Immortal heritage of henrietta lacks. Mol Gen Microbiol Virol 34: 195-200, 2019

73. Sassa S, Sugita O, Galbraith RA and Kappas A: Drug metabolism by the human hepatoma cell, Hep G2. Biochem Biophys Res Commun 143: 52-57, 1987.

74. Bouma ME, Rogier E, Verthier N, Labarre C and Feldmann G: Furthercellularinvestigation of the humanhepatoblastoma-derived cell line HepG2: Morphology and immunocytochemical studies of hepatic-secreted proteins. In Vitro Cell Dev Biol 25: 267-275, 1989.

75. Pan XP and Li LJ: Advances in cell sources of hepatocytes for bioartificial liver. Hepatobiliary Pancreat Dis Int 11: 594-605, 2012.

76. Lima CF, Fernandes-Ferreira M and Pereira-Wilson C: Phenolic compounds protect HepG2 cells from oxidative damage: Relevance of glutathione levels. Life Sci 79: 2056-2068, 2006.

77. Murota K and Terao J: Antioxidative flavonoid quercetin: Implication of its intestinal absorption and metabolism. Arch Biochem Biophys 417: 12-17, 2003. 
78. During A, Dawson HD and Harrison EH: Carotenoid transport is decreased and expression of the lipid transporters SR-BI, NPC1L1, and ABCA1 is downregulated in Caco-2 cells treated with ezetimibe. J Nutr 135: 2305-2312, 2005.

79. Rodriguez-Amaya DB: Quantitative analysis, in vitro assessment of bioavailability and antioxidant activity of food carotenoids A review. J Food Compos Anal 23: 726-740, 2010.

80. Scudiero DA, Shoemaker RH, Paull KD, Monks A, Tierney S, Nofziger TH, Currens MJ, Seniff D and Boyd MR: Evaluation of a soluble tetrazolium/formazan assay for cell growth and drug sensitivity in culture using human and other tumor cell lines. Cancer Res 48: 4827-4833, 1988

81. Meshulam T, Levitz SM, Christin L and Diamond RD: A simplified new assay for assessment of fungal cell damage with the tetrazoliumdye, (2,3)-bis-(2-methoxy-4-nitro-5-sulphenl)-(2H)-tetrazolium-5-carboxanil ide (XTT). J Infect Dis 172: 1153-1156, 1995.

82. Kerasioti E, Stagos D, Georgatzi V, Bregou E, Priftis A, Kafantaris I and Kouretas D: Antioxidant effects of sheep whey protein on endothelial cells. Oxid Med Cell Longev 2016: 6585737, 2016.

83. Goutzourelas N, Stagos D, Demertzis N, Mavridou P Karterolioti H, Georgadakis S, Kerasioti E, Aligiannis N, Skaltsounis L, Statiri A, et al: Effects of polyphenolic grape extract on the oxidative status of muscle and endothelial cells. Hum Exp Toxicol 33: 1099-1112, 2014.

84. Goutzourelas N, Stagos D, Spanidis Y, Liosi M, Apostolou A Priftis A, Haroutounian S, Spandidos DA, Tsatsakis AM and Kouretas D: Polyphenolic composition of grape stem extracts affects antioxidant activity in endothelial and muscle cells. Mol Med Rep 12: 5846-5856, 2015.

85. Priftis A, Panagiotou EM, Lakis K, Plika C, Halabalaki M, Ntasi G, Veskoukis AS, Stagos D, Skaltsounis LA and Kouretas D: Roasted and green coffee extracts show antioxidant and cytotoxic activity in myoblast and endothelial cell lines in a cell specific manner. Food Chem Toxicol 114: 119-127, 2018

86. Bajic VP, Van Neste C, Obradovic M, Zafirovic S, Radak D, Bajic VB, Essack M and Isenovic ER: Glutathione 'Redox Homeostasis' and its relation to cardiovascular disease. Oxid Med Cell Longev 2019: 5028181, 2019.

87. McLennan HR and Degli Esposti M: The contribution of mitochondrial respiratory complexes to the production of reactive oxygen species. J Bioenerg Biomembr 32: 153-162, 2000.

88. Asghar K, Reddy BG and Krishna G: Histochemical localization of glutathione in tissues. J Histochem Cytochem 23: 774-779, 1975.

89. Larrauri A, López P, Gómez-Lechón MJ and Castell JV: A cytochemical stain for glutathione in rat hepatocytes cultured on plastic. J Histochem Cytochem 35: 271-274, 1987.

90. Davey MW, Stals E, Panis B, Keulemans J and Swennen RL: High-throughput determination of malondialdehyde in plant tissues. Anal Biochem 347: 201-207, 2005.

91. Aguilar Diaz De Leon J and Borges CR: Evaluation of oxidative stress in biological samples using the thiobarbituric acid reactive substances assay. J Vis Exp: May 12, 2020 (Epub ahead of print). doi: $10.3791 / 61122$.

92. Keles MS, Taysi S, Sen N, Aksoy H and Akçay F: Effect of corticosteroid therapy on serum and CSF malondialdehyde and antioxidant proteins in multiple sclerosis. Can J Neurol Sci 28: 141-143, 2001.

93. Singh NP, Danner DB, Tice RR, Brant L and Schneider EL: DNA damage and repair with age in individual human lymphocytes. Mutat Res 237: 123-130, 1990.

94. Kasote DM, Katyare SS, Hegde MV and Bae H: Significance of antioxidant potential of plants and its relevance to therapeutic applications. Int J Biol Sci 11: 982-991, 2015.

95. Krishnaiah D, Sarbatly R and Nithyanandam R: A review of the antioxidant potential of medicinal plant species. Food Bioprod Process 89: 217-233, 2011.

96. Veskoukis AS, Kyparos A, Paschalis V and Nikolaidis MG: Spectrophotometric assays for measuring redox biomarkers in blood. Biomarkers 21: 208-217, 2016.

97. Veskoukis AS, Goutianos G, Paschalis V, Margaritelis NV, Tzioura A, Dipla K, Zafeiridis A, Vrabas IS, Kyparos A and Nikolaidis MG: The rat closely mimics oxidative stress and inflammation in humans after exercise but not after exercise combined with vitamin C administration. Eur J Appl Physiol 116 : 791-804, 2016.
98. Gerasopoulos K, Stagos D, Petrotos K, Kokkas S, Kantas D, Goulas P and Kouretas D: Feed supplemented with polyphenolic byproduct from olive mill wastewater processing improves the redox status in blood and tissues of piglets. Food Chem Toxicol 86: 319-327, 2015.

99. Makri S, Kafantaris I, Stagos D, Chamokeridou T, Petrotos K, Gerasopoulos K, Mpesios A, Goutzourelas N, Kokkas S, Goulas P, et al: Novel feed including bioactive compounds from winery wastes improved broilers' redox status in blood and tissues of vital organs. Food Chem Toxicol 102: 24-31, 2017.

100. Veskoukis AS, Tsatsakis A and Kouretas D: Approaching reactive species in the frame of their clinical significance: A toxicological appraisal. Food Chem Toxicol 138: 111206, 2020.

101. Marrocco I, Altieri F and Peluso I: Measurement and clinical significance of biomarkers of oxidative stress in humans. Oxid Med Cell Longev 2017: 6501046, 2017.

102. Jones B and Kenward MG: Design and Analysis of Cross-Over Trials. In: Chapman \& Hall/CRC Monographs on Statistics and Applied Probability, 2015.

103. Matthaiou CM, Goutzourelas N, Stagos D, Sarafoglou E, Jamurtas A, Koulocheri SD, Haroutounian SA, Tsatsakis AM and Kouretas D: Pomegranate juice consumption increases GSH levels and reduces lipid and protein oxidation in human blood. Food Chem Toxicol 73: 1-6, 2014.

104. Yagi K: Assay for blood plasma or serum. Methods Enzymol 105: 328-331, 1984

105. Fedorova M, Bollineni RC and Hoffmann R: Protein carbonylation as a major hallmark of oxidative damage: Update of analytical strategies. Mass Spectrom Rev 33: 79-97, 2014.

106. Levine R: Oxygen radicals in biological systems. Part B: Oxygen radicals and antioxidants. Methods Enzymol 186: 1-766, 1990.

107. Janaszewska A and Bartosz G: Assay of total antioxidant capacity: Comparison of four methods as applied to human blood plasma. Scand J Clin Lab Invest 62: 231-236, 2002.

108. Reddy YN, Murthy SV, Krishna DR and Prabhakar MC: Role of free radicals and antioxidants in tuberculosis patients. IJTB 51: 213-218, 2004.

109. Aebi H: Catalase in vitro. Methods Enzymol 105: 121-126, 1984

110. Sepasi Tehrani $\mathrm{H}$ and Moosavi-Movahedi AA: Catalase and its mysteries. Prog Biophys Mol Biol 140: 5-12, 2018

111. Wilson DW, Nash P, Buttar HS, Griffiths K, Singh R, De Meester F, Horiuchi R and Takahashi T: The role of food antioxidants, benefits of functional foods, and influence of feeding habits on the health of the older person: An overview. Antioxidants 6: 6, 2017

112. Abuajah CI, Ogbonna AC and Osuji CM: Functional components and medicinal properties of food: A review. J Food Sci Technol 52: 2522-2529, 2015

113. Alkhatib A, Tsang C, Tiss A, Bahorun T, Arefanian H, Barake R, Khadir A and Tuomilehto J: Functional foods and lifestyle approaches for diabetes prevention and management. Nutrients 9: 9, 2017

114. Konstantinidi $\mathrm{M}$ and Koutelidakis AE: Functional foods and bioactive compounds: A review of its possible role on weight management and obesity's metabolic consequences. Medicines (Basel) 6: 6, 2019.

115. Azman KF and Zakaria R: Honey as an antioxidant therapy to reduce cognitive ageing. Iran J Basic Med Sci 22: 1368-1377, 2019.

116. Ahmed S, Sulaiman SA, Baig AA, Ibrahim M, Liaqat S, Fatima S, Jabeen S, Shamim N and Othman NH: Honey as a potential natural antioxidant medicine: an insight into its molecular mechanisms of action. Oxid Med Cell Longev 2018: 8367846, 2018.

117. Almasaudi SB, El-Shitany NA, Abbas AT, Abdel-dayem UA, Ali SS, Al Jaouni SK and Harakeh S: Antioxidant, anti-inflammatory, and antiulcer potential of manuka honey against gastric ulcer in rats. Oxid Med Cell Longev 2016: 3643824, 2016.

118. Chua LS, Rahaman NL, Adnan NA and Eddie Tan TT: Antioxidant activity of three honey samples in relation with their biochemical components. J Anal Methods Chem 2013: 313798, 2013.

119. Gül A and Pehlivan T: Antioxidant activities of some monofloral honey types produced across Turkey. Saudi J Biol Sci 25: 1056-1065,

(i) (2) This work is licensed under a Creative Commons

Attribution-NonCommercial-NoDerivatives 4.0 International (CC BY-NC-ND 4.0) License. 